\title{
Scavenging amphipods from the Wallaby-Zenith Fracture Zone: Extending the hadal paradigm beyond subduction trenches
}

\author{
Johanna N. J. Weston ${ }^{1}$ (1) $\cdot$ Rachael A. Peart ${ }^{2} \cdot$ Heather A. Stewart ${ }^{3} \cdot$ Heather Ritchie $^{5} \cdot$ Stuart B. Piertney $^{4}$. \\ Thomas D. Linley ${ }^{1} \cdot$ Alan J. Jamieson ${ }^{1}$
}

Received: 6 May 2020 / Accepted: 28 October 2020 / Published online: 21 December 2020

(c) The Author(s) 2020

\begin{abstract}
Our understanding of the ecology of the hadal zone (>6000 $\mathrm{m}$ depth) is based solely on subduction trenches, leaving other geomorphological features, such as fracture zones, troughs, and basins, understudied. To address this knowledge gap, the Wallaby-Zenith Fracture Zone, Indian Ocean (WZFZ; $22^{\circ} \mathrm{S}, 102^{\circ} \mathrm{E}$; maximum depth $6625 \mathrm{~m}$ measured during Expedition SO258) was studied using free-fall baited landers. We assessed the amphipod distribution and community assemblage of this non-subduction hadal feature and compared it to subduction hadal features. Eleven species were identified across the abyssal-hadal transition zone using a paired morphological and DNA barcoding approach. The community composition was found to change gradually from abyssal to hadal depths, which contrasts with the ecotone shift characteristic of subduction trenches. A large population of Bathycallisoma schellenbergi (Birstein \& Vinogradov, 1958), a quintessential hadal amphipod, was present at the flat bottom of the WZFZ. Further, an mtDNA phylogeny resolved a degree of phylogeographic structure between the B. schellenbergi WZFZ population and four previously sampled Pacific Ocean subduction trench populations, indicating these features are not interconnected through ongoing gene flow. Combined, these data indicate that some amphipods have far broader distributions than previously understood, with some species present in both hadal subduction trenches and non-subduction fracture zones and basins interspersed across the abyssal plains. This initial exploration highlights that whilst non-subduction features are an overlooked minor fraction of the total hadal area, they are essential to our understanding of the ecological and evolutionary dynamics across the hadal zone.
\end{abstract}

Responsible Editor: H. J. T. Hoving.

Reviewed by K. Linse and undisclosed experts.

Electronic supplementary material The online version of this article (https://doi.org/10.1007/s00227-020-03798-4) contains supplementary material, which is available to authorized users.

Johanna N. J. Weston

J.Weston2@newcastle.ac.uk

1 School of Natural and Environmental Sciences, Newcastle University, Newcastle Upon Tyne NE1 7RU, UK

2 National Institute of Water \& Atmospheric Research (NIWA), 301 Evans Bay Parade, Wellington 6021, New Zealand

3 British Geological Survey, Lyell Centre, Research Avenue South, Edinburgh EH14 4AP, UK

4 School of Biological Sciences, University of Aberdeen, Zoology Building, Tillydrone Avenue, Aberdeen AB24 2TZ, UK

5 X-STAR, Japan Agency for Marine-Earth Science and Technology (JAMSTEC), 2-15 Natsushima-cho, Yokosuka, Kanagawa 237-0061, Japan

\section{Introduction}

The hadal zone comprises 47 known, geographically disjunct, marine features that extend deeper than $6000 \mathrm{~m}$ below sea level. Of these, 27 are subduction trenches situated at tectonic plate subduction boundaries and account for $93.7 \%$ of the total hadal area $\left(\sim 750,000 \mathrm{~km}^{2}\right.$; Jamieson 2015$)$. The remaining features are troughs, fracture zones, trench faults, and other features that are not necessarily associated with plate convergence zones and can span across the abyssal plain interiors $\left(\sim 50,500 \mathrm{~km}^{2}\right.$; Jamieson 2015$)$. Whilst these features all experience high hydrostatic pressure, low temperature, and limited food availability, the geomorphological characteristics, such as total depth, total area, geographic isolation, seismicity, geologic age, and topographic complexity, vary widely between each habitat (Stewart and Jamieson 2018).

These deep marine regions host faunal communities with a high degree of endemism, comprised crustaceans, echinoderms, polychaetes, molluscs, foraminifera, cnidarians, 
and fishes (Wolff 1960, 1970; Beliaev 1989). Patterns of population and community structure, and species distribution are being uncovered with an increase in the number of hadal sampling expeditions since 2000 and the preferential use of baited landers to visualize the seafloor and study baitattending fauna (Lacey et al. 2016; Jamieson 2018). Much of our recent understanding has largely focused on scavenging amphipods (Fujii et al. 2013; Eustace et al. 2016; Lacey et al. 2016). Scavenging amphipods, primarily from the Lysianassoidea and Allicelloidea superfamilies, are abundant in the deep sea benthic community and dominate at depths greater than $8000 \mathrm{~m}$ (Ritchie et al. 2015; Lacey et al. 2016). As scavenging amphipods can be readily and consistently recovered in large numbers via baited trap landers, they represent model taxa to study the ecological dynamics of the abyssal and hadal zones across the wide variation of geomorphic settings (Fujii et al. 2013; Duffy et al 2016; Lacey et al. 2016).

The faunal community at hadal subduction trenches is distinct from, and not merely an extension of, the abyssal faunal community (Wolff 1970; Beliaev 1989; Jamieson et al. 2011). At the Kermadec, New Hebrides, and Peru-Chile trenches, the scavenging amphipod communities have been documented to abruptly shift from an abyssal to hadal community (Jamieson et al. 2011, Fujii et al. 2013; Lacey et al. 2016), with similar shifts documented in sediment microbial (Hiraoka et al. 2020) and bait-attending fish (Linley et al. 2017) communities. This shift has been interpreted to reflect the presence of an ecotone boundary between zones (Jamieson et al. 2011). Whilst the hadal zone is bluntly defined to begin at $6000 \mathrm{~m}$, the community shift occurs at some depth between 6000 and $7000 \mathrm{~m}$ depending on the feature (Jamieson et al. 2011, Fujii et al. 2013; Lacey et al. 2016). For instance, this shift has been documented to occur between 6097 and $6709 \mathrm{~m}$ in the Kermadec Trench (Lacey et al. 2016) and 6173-7050 $\mathrm{m}$ in the Peru-Chile Trench (Fujii et al. 2013). The amongst-trench variation coincides with the break-in slope between the abyssal plain and the subduction trench (Lacey et al. 2016). This further indicates that rapid changes in environmental factors and topography at the trench boundary, differing between the trenches, contribute to the distinct faunal change. Additionally, there are inter-trench assemblage differences (Eustace et al. 2013; Lacey et al. 2016; Jażdżewska and Mamos 2019), which may be attributed to the amount of particulate organic carbon flux (Ichino et al. 2015) and species evolutionary history and physiological pressure tolerance (Downing et al. 2018).

The trench scavenging amphipod communities at hadal depths appear to be largely dominated by a few species. These species include Hirondellea gigas (Birstein \& Vinogradov, 1955) in the northwest Pacific Ocean trenches (Hessler et al. 1978; France 1993; Eustace et al. 2013; Jażdżewska and Mamos 2019), Hirondellea dubia Dahl,
1959 largely in the southwest Pacific Ocean trenches (Blankenship et al. 2006; Lacey et al. 2016), and Eurythenes sp. and Hirondellea thurstoni Kilgallen, 2015 in the Peru-Chile Trench (Eustace et al. 2016; Lacey et al. 2016). Bathycallisoma schellenbergi (Birstein \& Vinogradov, 1958) is a cosmopolitan hadal species found in trenches across four oceans (Kilgallen and Lowry 2015). Populations of these species have been observed to exhibit ontogenetic vertical stratification, whereby juveniles inhabit the shallower depths, and adults, primarily females, reside in the deeper depths (Blankenship et al. 2006; Eustace et al. 2013, 2016; Lacey et al. 2018). Further, this intra-specific partitioning has been found to scale to the topography of the trench (Lacey et al. 2018). This consistency of ontogenetic vertical stratification indicates that the population structure of scavenging amphipods in trenches is not solely driven by depth but also the physiological constraints involving hydrostatic pressure, predator avoidance, and food distribution driven by topography.

Hadal subduction trench ecosystems are often purported to be evolutionarily and demographically independent units. Whilst this holds for certain species, like Eurythenes sp. from hadal depths of the Peru-Chile Trench (Eustace et al. 2016) and some hadal snailfish (Linley et al. 2016), a growing body of evidence challenges this traditional understanding, e.g., H. dubia (Ritchie et al. 2015) and B. schellenbergi (Kilgallen and Lowry 2015). Indeed, population genetic analysis has shown that occasional gene flow does occur between five disparate, abyssal populations of Paralicella spp. across the Pacific Ocean (Ritchie et al. 2017). How this is mediated over such large geographical expanses remains unclear.

The study of hadal amphipod ecology has so far been limited to subduction trenches and whether the diversity and community composition patterns are reflective across the hadal zone remains unresolved. Specifically, are species diversity and community structure patterns at hadal depth simply a function of being 'hadal' (depth) or driven by geomorphic and seismic processes? Resolving this requires sampling across the abyssal-hadal transition zone of nonsubduction features, specifically areas that have few topographical and seismic similarities to subduction trenches.

To begin to address this knowledge and sampling gap, we present the first biological investigation of a non-subduction hadal feature, the Wallaby-Zenith Fracture Zone (WZFZ) in the Indian Ocean and the abyssal base of the Afanasy Nikitin Seamount as a comparative Indian Ocean reference point. In this study, we describe the geomorphology of the WZFZ based on multibeam mapping and include characterisation of the seafloor habitat based on in situ imaging. We examine three aspects of the amphipod community for both features, namely the community composition across the abyssalhadal transition zone, demographics of the dominant hadal 
species $B$. schellenbergi, and the phylogeographic relationships between the WZFZ $B$. schellenbergi population and four previously sampled Pacific Ocean subduction trench populations.

\section{Materials and methods}

\section{Study region}

The WZFZ is part of the larger Wharton Basin and Perth Basin complex. The nearest hadal features are the Java Trench, $2100 \mathrm{~km}$ north, and the Diamantina Fracture Zone, $1300 \mathrm{~km}$ south (Fig. 1a; Daniell et al. 2010). The WZFZ formed as a transform fault between 130 and 124 Ma with the opening of the Indian Ocean during the breakup of the Greater India and Australia (Veevers and Cotterill 1978; White et al. 2013; Olierrok et al. 2015). Extending south of the Zenith Plateau, the WZFZ spans an area of $12,960 \mathrm{~km}^{2}$. Two elongated depressions account for $32 \%$ of the total area, in addition to four other geomorphic features (i.e., terrace, non-incised slope, ridge, and scarp; Daniell et al. 2010). The WZFZ is positioned under the Indian Ocean South Subtropical Gyre biogeochemical province (Longhurst et al. 1995).

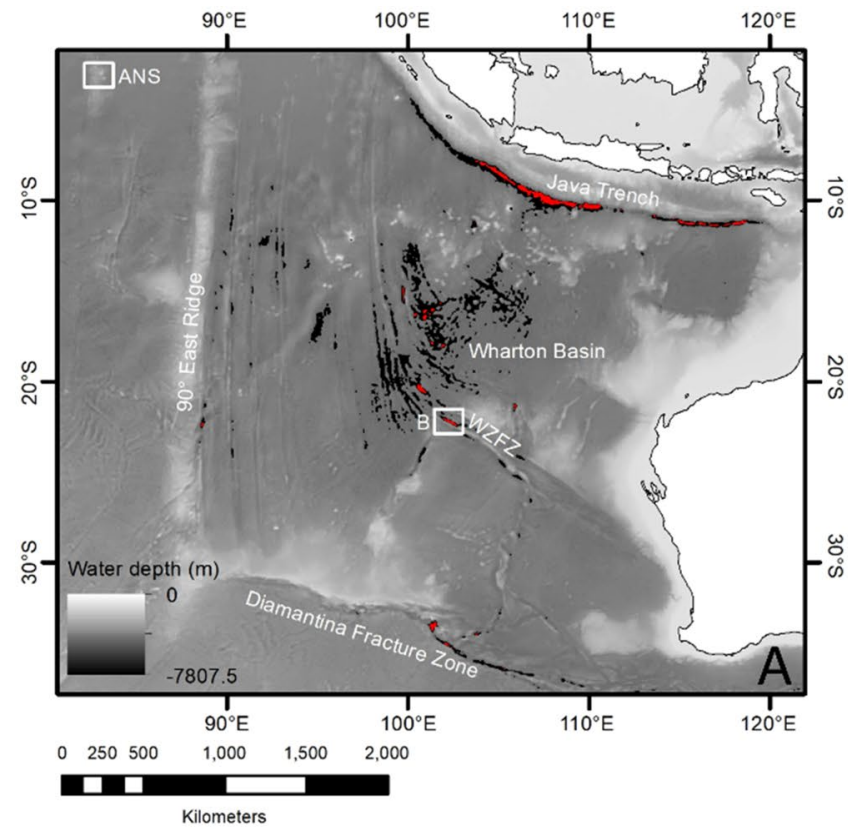

Fig. 1 a Map of two study sites in the East Indian Ocean with major features labelled and areas with a depth of 6000-6500 m in black and $>6500 \mathrm{~m}$ in red. b Subset of multibeam bathymetry data acquired over the Zenith Plateau and Wallaby-Zenith Fracture Zone [for location see (a)], lander deployments where amphipods were collected (black circles), lander deployments with only camera data acquired (white circles) are shown. Regional bathymetric data displayed in
The Afanasy Nikitin Seamount is part of the Central Indian Basin and located at the southern end of the $85^{\circ} \mathrm{E}$ Ridge (Fig. 1a; Sclater and Fischer 1974; Sborshchikov et al. 1995). Formed 80-73 Ma by the Conrad Rise hotspot, the main plateau rises to $\sim 1200 \mathrm{~m}$ above the surrounding $4800 \mathrm{~m}$ ocean floor (Krishna et al. 2014). The Afanasy Nikitin Seamount is positioned under the Indian Ocean Monsoon Gyres biogeochemical province (Longhurst et al. 1995).

\section{Physical mapping}

The WZFZ and Afanasy Nikitin Seamount were studied as part of the $R / V$ SONNE Expedition SO258 Leg 1 in June-July 2017 (Werner et al. 2017). Prior to the expedition, satellite altimetry estimated the WZFZ to have a maximum depth of $7883 \mathrm{~m}$ (Smith and Marks 2014; Marghany et al. 2016). Although, recent studies have demonstrated that the error associated with satellite altimetry measurements is elevated at depths exceeding $3000 \mathrm{~m}$ (e.g., Weatherall et al. 2015; Mayer et al. 2018; Stewart and Jamieson 2019). The $R / V$ SONNE is equipped with a Kongsberg EM122 full ocean depth multibeam echosounder, which was operated by onboard operators. Werner et al. (2017)

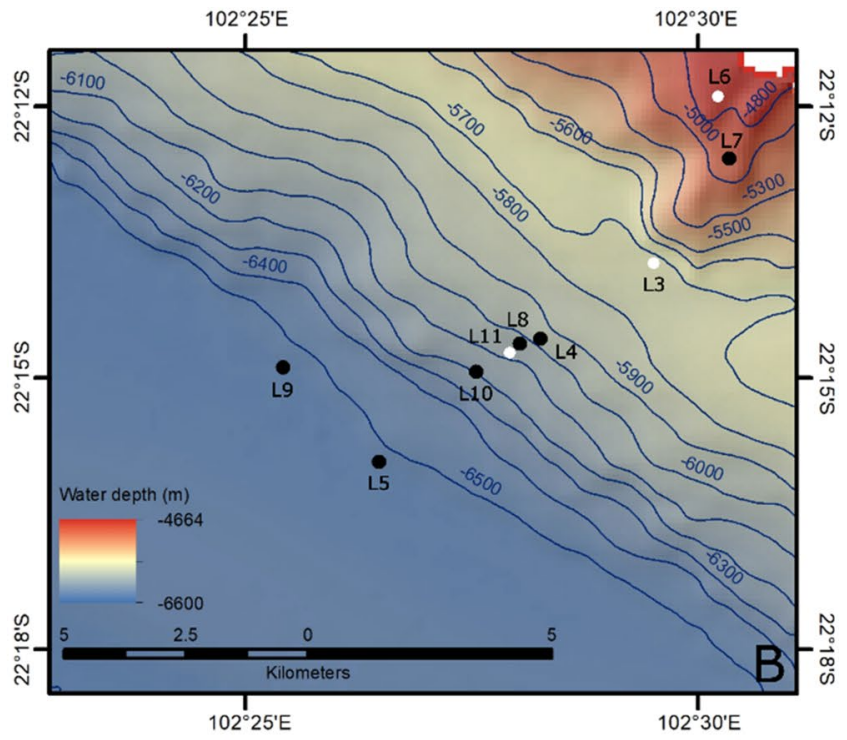

(a) sourced from the Global Multi-Resolution Topography Synthesis (Ryan et al. 2009). Multibeam bathymetric data displayed in (b) sourced from $R / V$ SONNE Expedition SO258 (Werner et al. 2017). ANS is Afanasy Nikitin Seamount, and WZFZ is Zenith Plateau \& Wallaby-Zenith Fracture Zone. Multibeam bathymetric map for ANS can be found in Fig. S2 
include details on system acquisition parameters and data processing of the multibeam bathymetry data.

\section{Biological sampling and processing}

Five autonomous landers (three imaging and two baited trap landers; Jamieson et al. 2009b) were launched and recovered nine times from the top of the Zenith Plateau, along the northern ridge, to the base of the WZFZ from June 10 to 12, 2017 (Fig. 1b) and three times to the base of the Afanasy Nikitin Seamount on June 29, 2017 (Fig. S2; Table 1). The sampled depth ranges spanned from 4747 to $6546 \mathrm{~m}$ at the WZFZ and 4724-4757 $\mathrm{m}$ at the Afanasy Nikitin Seamount. Landers remained at depth for 7-10 $\mathrm{h}$ and were equipped with a temperature and pressure sensor (SBE-39, SeaBird Electronics, US). Pressure (dbar) was converted to depth (m) following Saunders (1981). Imaging landers were outfitted with bespoke HD video and still cameras to characterise the substrate. The cameras were located $2 \mathrm{~m}$ above the seafloor looking vertically down. Specimens were collected with the baited trap landers, which were equipped with 2-L funnel traps baited with whole mackerel (Scombridae; Jamieson et al. 2011). Upon recovery and initial sorting, amphipods were preserved using $70 \%$ ethanol.

An integrated taxonomic approach was taken as deep sea amphipod identification is challenged by phenotypic plasticity, and intra-specific and ontogenetic variation (Ritchie et al. 2015; Weston et al. 2020). Amphipods were morphologically identified to lowest rank possible, following Barnard and Ingram (1990) and Barnard and Karaman (1991), with updates after Lowry and De Broyer (2008), Lowry and Kilgallen (2014), d'Udekem d'Acoz and Havermans (2015), Kilgallen (2015), and Kilgallen and Lowry (2015).

A total of 25 amphipods were selected for DNA barcoding to support morphological identification. The individuals were chosen to represent at least one individual of each species or morphospecies and, where possible, coverage at multiple depths. Total genomic DNA was extracted using the Bioline ISOLATE II Genomic DNA Kit. Partial regions of the mitochondrial 16S rRNA gene (16S) and cytochrome $\mathrm{c}$ oxidase subunit I (COI) were amplified with published primer sets: AMPH1 (France and Kocher 1996) and 'Drosophila-type' $16 \mathrm{SBr}$ (Palumbi et al. 2002) for $16 \mathrm{~S}$ and LCO1490 and HCO12198 (Folmer et al. 1994) for COI. PCR protocols were followed as described in Ritchie et al. (2015). Sequences were cleaned enzymatically using New England Biolabs Exonuclease 1 and Antarctic Phosphatase and sequenced with an ABI 3730XL sequencer (Eurofins Genomics, Germany).

Electropherograms were examined in MEGA v7 (Kumar et al. 2016), primer and ambiguous sequences were clipped by eye, and COI sequences were translated into equivalent amino acid sequences to confirm an absence of stop codons. Each sequence was compared with species diagnostic barcodes on NCBI using BLASTn with default parameters. Individuals were identified to species-level with a $98-100 \%$ match and to genus-level with $>90 \%$. Final identifications were determined by accounting for both morphological and DNA barcoding identifications.

\section{Amphipod community composition}

The amphipod community was characterised using a cluster analysis and non-metric dimensional scaling (nMDS) ordination approach to identify structure and trends across the abyssal-hadal transition zone. Amphipod counts by depth were first divided by the deployment time (h) to standardize for sampling effort and then fourth root-transformed to account for the influence of highly abundant species. The transformed data were converted into a Bray-Curtis
Table 1 Imaging and baited trap lander stations

\begin{tabular}{lllllll}
\hline Depth $(\mathrm{m})$ & Latitude & Longitude & Station & Date & Location & Lander \\
\hline 4767 & $2211.898 \mathrm{~S}$ & $10230.221 \mathrm{E}$ & L6 & $11 / 6 / 2017$ & ZP & Imaging \\
4932 & $2212.579 \mathrm{~S}$ & $10230.347 \mathrm{E}$ & L7 & $11 / 6 / 2017$ & ZP & Trap \\
5724 & $2213.741 \mathrm{~S}$ & $10229.515 \mathrm{E}$ & L3 & $10 / 6 / 2017$ & WZFZ & Imaging \\
5990 & $2214.574 \mathrm{~S}$ & $10228.262 \mathrm{E}$ & L4 & $10 / 6 / 2017$ & WZFZ & Trap \\
6068 & $2214.628 \mathrm{~S}$ & $10228.037 \mathrm{E}$ & L8 & $11 / 6 / 2017$ & WZFZ & Trap \\
6084 & $2214.730 \mathrm{~S}$ & $10227.919 \mathrm{E}$ & L11 & $12 / 6 / 2017$ & WZFZ & Imaging \\
6162 & $2214.939 \mathrm{~S}$ & $10227.554 \mathrm{E}$ & L10 & $12 / 6 / 2017$ & WZFZ & Trap \\
6537 & $2215.931 \mathrm{~S}$ & $10226.477 \mathrm{E}$ & L5 & $10 / 6 / 2017$ & WZFZ & Imaging \\
6546 & $2214.887 \mathrm{~S}$ & $10225.415 \mathrm{E}$ & L9 & $11 / 6 / 2017$ & WZFZ & Trap \\
4724 & $308.932 \mathrm{~S}$ & $8226.007 \mathrm{E}$ & L12 & $29 / 6 / 2017$ & ANS & Imaging \\
4733 & $309.236 \mathrm{~S}$ & $8225.986 \mathrm{E}$ & L13 & $29 / 6 / 2017$ & ANS & Trap \\
4757 & $309.542 \mathrm{~S}$ & $8225.993 \mathrm{E}$ & L14 & $29 / 6 / 2017$ & ANS & Trap \\
\hline
\end{tabular}

Location abbreviations: ZP Zenith Plateau, WZFZ Wallaby-Zenith Fracture Zone, ANS Afanasy Nikitin Seamount 
similarity matrix and a hierarchical cluster analysis (group-average linkage) was performed (Fujii et al. 2013; Lacey et al. 2016). A similarity profile analysis permutation test (SIMPROF; Clarke et al. 2008; significance level of $p<0.05$ ) was conducted to identify the number of significant clusters or 'communities'. A similarity percentage analysis (SIMPER) was applied to identify the species of greatest similarity within a community and those species most responsible for the differences between the SIMPROF communities. Standardization by deployment time was conducted in Excel, and subsequent analysis was conducted in PRIMER v7 (Clarke and Gorley 2015).

The WZFZ and Afanasy Nikitin Seamount data were assessed and compared with abundance data from 32 sites at bathyal to hadal depths (1488-9908 m) at the South Fiji Basin and the Kermadec, New Hebrides, and Peru-Chile trenches (Fujii et al. 2013; Lacey et al. 2016). The identification of Eurythenes gryllus (Lichtenstein in Mandt 1822) presented in Fujii et al. (2013) was updated to reflect the three morphospecies of Eurythenes present in the Peru-Chile Trench (Eustace et al. 2016). The multivariate analysis was conducted at species-level and genus-level identifications. Assessment with genus-level identification was done to remove identification bias due to lack of intact specimens, cryptic speciation, and/or specimens requiring description.

\section{Bathycallisoma schellenbergi demographics and phylogeography}

The biometric data of the dominant hadal species, $B$. schellenbergi, were analysed to characterise the sex and stage structure of the population. Specimens were classified as a male with the presence of penile papillae, female with the presence of oostegites, juvenile with the lack of penile papillae and oostegites, and intersex with the presence of both penile papillae and oostegites (Eustace et al. 2013; Lacey et al. 2018). Total body length was measured from the tip of the rostrum to the end of the telson with straightened posture using digital callipers (Fisher Scientific with a resolution of $0.1 \mathrm{~mm} \pm 0.2 \mathrm{~mm}$; Lacey et al. 2018). The coxa 4 length was measured diagonally across the coxa and used as a proxy for total body length for damaged individuals. Deviations from an expected 1: 1 ratio for sex (female versus male) and maturity (adult versus juvenile) at $6537 \mathrm{~m}$ and $6546 \mathrm{~m}$ were evaluated using a one-tailed binomial test $(\alpha=0.05)$. The intersex individual was included in the maturity bias analysis but excluded from the sex bias analysis. The number of cohorts or stages based on coxa 4 length was assessed with the mixdist package v0.5-5 (Duffy et al. 2016; Macdonald 2018). The analysis was conducted in $\mathrm{R} v 3.4 .2$ with the stats package (R Core Team 2017).

A concatenated $16 \mathrm{~S}$ and COI dataset was constructed to investigate phylogeographic relationships between $B$. schellenbergi hadal populations from the WZFZ and four Pacific Ocean populations, specifically the Kermadec, Tonga, New Hebrides, and Massau (also known as Mussau) trenches. The comparative sequences comprised seven individuals, which represent the only $16 \mathrm{~S}$ and $\mathrm{COI}$ sequences publicly available on GenBank for B. schellenbergi (Table S3; Ritchie et al. 2015; Blankenship et al. unpublished data; Chan et al. unpublished data). The phylogeny was rooted by $H$. dubia and $H$. gigas (Table S3; Ritchie et al. 2015), as they are both hadal scavengers and the Hirondelleidae family is sufficiently distant from the Scopelocheiridae family (Ritchie et al. 2015).

Nucleotide sequences were aligned with MAFFT v7 (Katoh et al. 2017). The optimal evolutional model for each $16 \mathrm{~S}$ and COI alignment was identified by modeltest in the phangorn v2.4.0 package (Schliep 2011; Schliep et al. 2017) in R v3.4.2. The optimal Akaike Information Criterion and the Bayesian Information Criterion indicated the best-fit models as the Hasegawa, Kishino, and Yano model (HKY) for 16S and the HKY with gamma distribution for COI (Hasegawa et al. 1985). Phylogeographic relationships were constructed via a maximum-likelihood approach using PhyML v3.1 (Guindon et al. 2010) and a Bayesian approach using the Bayesian Evolutionary Analysis by Sampling Trees (BEAST) software package v1.8.4 (Drummond et al. 2012). Maximum-likelihood analyses were conducted with a neighbour-joining starting tree and nearest neighbour interchange branch swapping using the model of sequence evolution and parameters estimated by PhyML. The stability of nodes was assessed from bootstrap support based upon 10,000 iterations. Bayesian analyses were undertaken in two independent runs, which were performed for 40,000,000 generations sampling every 10,000 generations using the respective evolutionary models and an uncorrelated relaxed clock. Outputs were assessed with Tracer v1.7 to ensure convergence (effective sample size $>200$; Rambaut et al. 2018) and combined in LogCombiner v1.8.4. The first 4,000,000 states were discarded. The maximum clade credibility tree was generated through TreeAnnotator v1.8.4, viewed in FigTree v1.4.3, and annotated using Inkscape v0.92.2. A Bayesian Poisson Tree Processes (bPTP) model was used to delineate species (Zhang et al. 2013).

\section{Results}

\section{Habitat and environmental conditions}

The WZFZ was flat-bottomed. The deepest point, at $6625 \mathrm{~m}$, was located approximately $12 \mathrm{~km}$ south of Station L9 (6546 m; Fig. S1). The surface area of the WZFZ deeper than $6000 \mathrm{~m}$ was $2798 \mathrm{~km}^{2}$ and only $1059 \mathrm{~km}^{2}$ for areas deeper than $6500 \mathrm{~m}$. 
At the WZFZ, the near-bottom temperatures varied from $1.14{ }^{\circ} \mathrm{C}$ at $4767 \mathrm{~m}$ to $1.32{ }^{\circ} \mathrm{C}$ at $6537 \mathrm{~m}$. At the Zenith Plateau, a manganese nodule field comprising nodules up to $7 \mathrm{~cm}$ in diameter were located within a fine-grained matrix (Fig. S3). At $5274 \mathrm{~m}$ in the WZFZ, a poorly sorted substrate was encountered comprising irregularly shaped gravel and cobble-sized material within a fine-grained matrix (Fig. S3). Some of this material could be comprised manganese nodules. Similarly, at $6084 \mathrm{~m}$, the substrate comprised fine-grained sediments with lesser amounts of gravels and cobbles up to $\sim 6 \mathrm{~cm}$ in diameter of mixed composition (Fig. S3). At the Afanasy Nikitin Seamount, the bottom temperature was $1.42{ }^{\circ} \mathrm{C}$ at $4724 \mathrm{~m}$ and the seafloor was composed of predominantly fine-grained sediment with a small number of gravel-sized fragments of unknown composition (Fig. S3).

\section{Amphipod community composition}

A total of 3864 amphipods were sampled from the Zenith Plateau and WZFZ, and 203 amphipods were samples from the Afanasy Nikitin Seamount comprising 13 species from eight families: Alicellidae (4), Uristidae (3), Cylocaridae (1), Eurytheneidae (1), Eusiridae (1), Hirondelleidae (1), Scopelocheiridae (1), and Valettiopsidae (1) (Fig. 2; Table S1). Two species have been formally described from material collected by this sampling effort, Stephonyx sigmacrus Weston, Peart, \& Jamieson, 2020 (Lysianassoidea: Uristidae) and Civifractura serendipia Weston, Peart, \& Jamieson, 2020 (Allicelloidea: Alicellidae; Weston et al. 2020). Further, four additional species have not been previously described. The $2516 \mathrm{~S}$ and $21 \mathrm{COI}$ sequences used to inform species identification were deposited into GenBank (16S: MN251311-MN251335 \& COI: MN26162-MN262182; Table S2).

Five species were present at both the WZFZ and Afanasy Nikitin Seamount, specifically Eurythenes maldoror d'Udekem d'Acoz \& Havermans, 2015, Alicella gigantea Chevreux, 1899, Paralicella caperesca Shulenberger \& Barnard, 1976, Paralicella. tenuipes Chevreux, 1908, and Cyclocaris sp. nov. Whilst Abyssorchomene gerulicorbis (Shulenberger \& Barnard, 1976), Civifractura serendipia, B. schellenbergi, Valettietta sp. nov., S. sigmacrus, and Cleonardo sp. indent. were only present at the Zenith Plateau and WZFZ, and Hirondellea sp. nov. and Abyssorchomene distinctus (Birstein and Vinogradov 1960) were only recovered from the Afanasy Nikitin Seamount. At abyssal depths, $P$. tenuipes and $P$. caperesca were numerically dominant, with $P$. tenuipes present at every depth. The relative abundance of $P$. tenuipes decreased from $96.5 \%$ at $6162 \mathrm{~m}$ to $61.7 \%$ at $6537 \mathrm{~m}$, which coincided with the presence of B. schellenbergi. Bathycallisoma schellenbergi was only present at 6537 and $6546 \mathrm{~m}$ and accounted for $32.6 \%$ and $55 \%$ of the catch, respectively. Cluster analysis between the Zenith Plateau, WZFZ, and Afanasy Nikitin Seamount did not identify any significant groupings (average similarity $57.23 \%$; Table S4).

Six distinct communities were identified in comparing the eight East Indian Ocean sites with 32 Pacific Ocean sites at species-level identification (Fig. 3a; Fujii et al. 2013; Lacey et al. 2016). The East Indian Ocean sites were delimited within Cluster 4 . The comparative sites comprised Clusters $1,2,3,5$, and 6 . The comparative site clustering was nearly
Fig. 2 Relative abundance of amphipod species identified by depth from the Zenith Plateau \& Wallaby-Zenith Fracture Zone, and the Afanasy Nikitin Seamount. The asterisks indicate potentially undescribed species

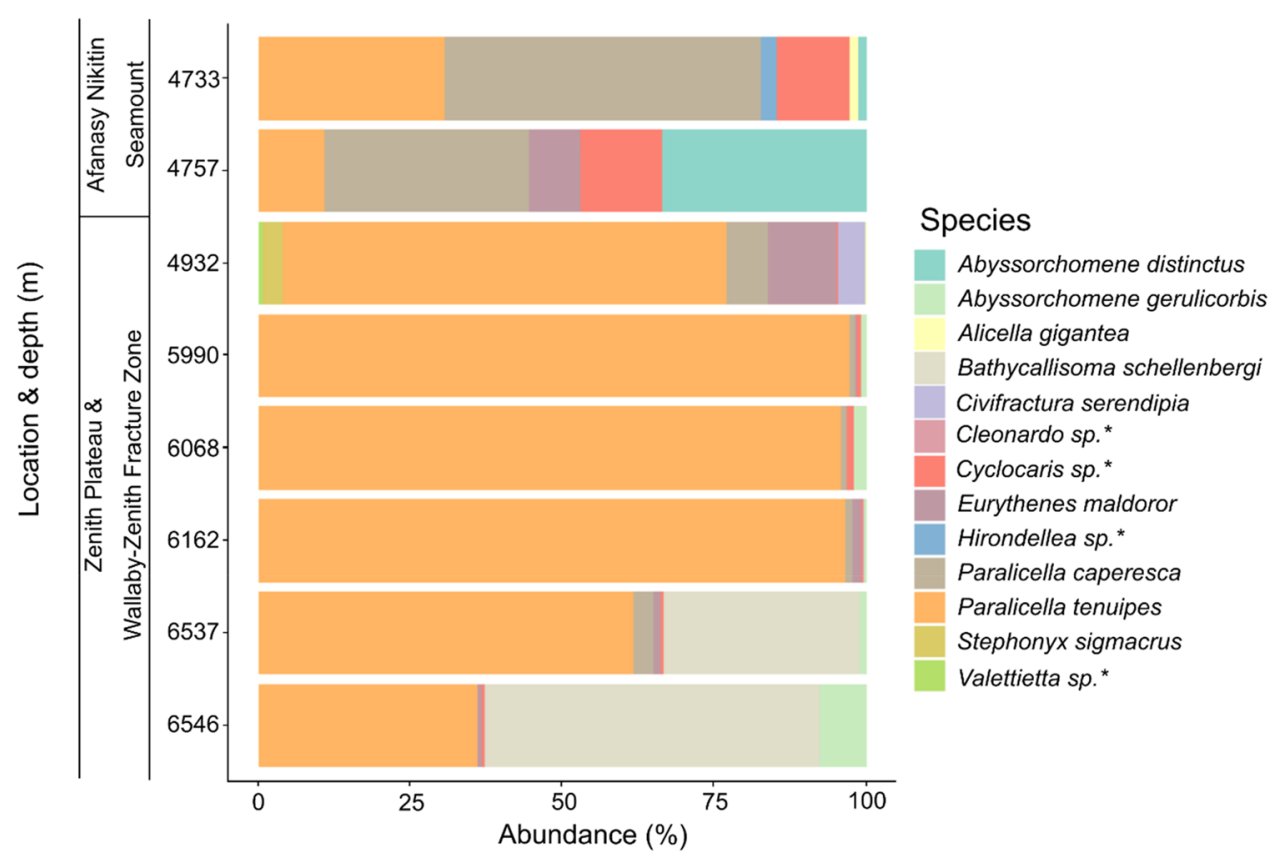




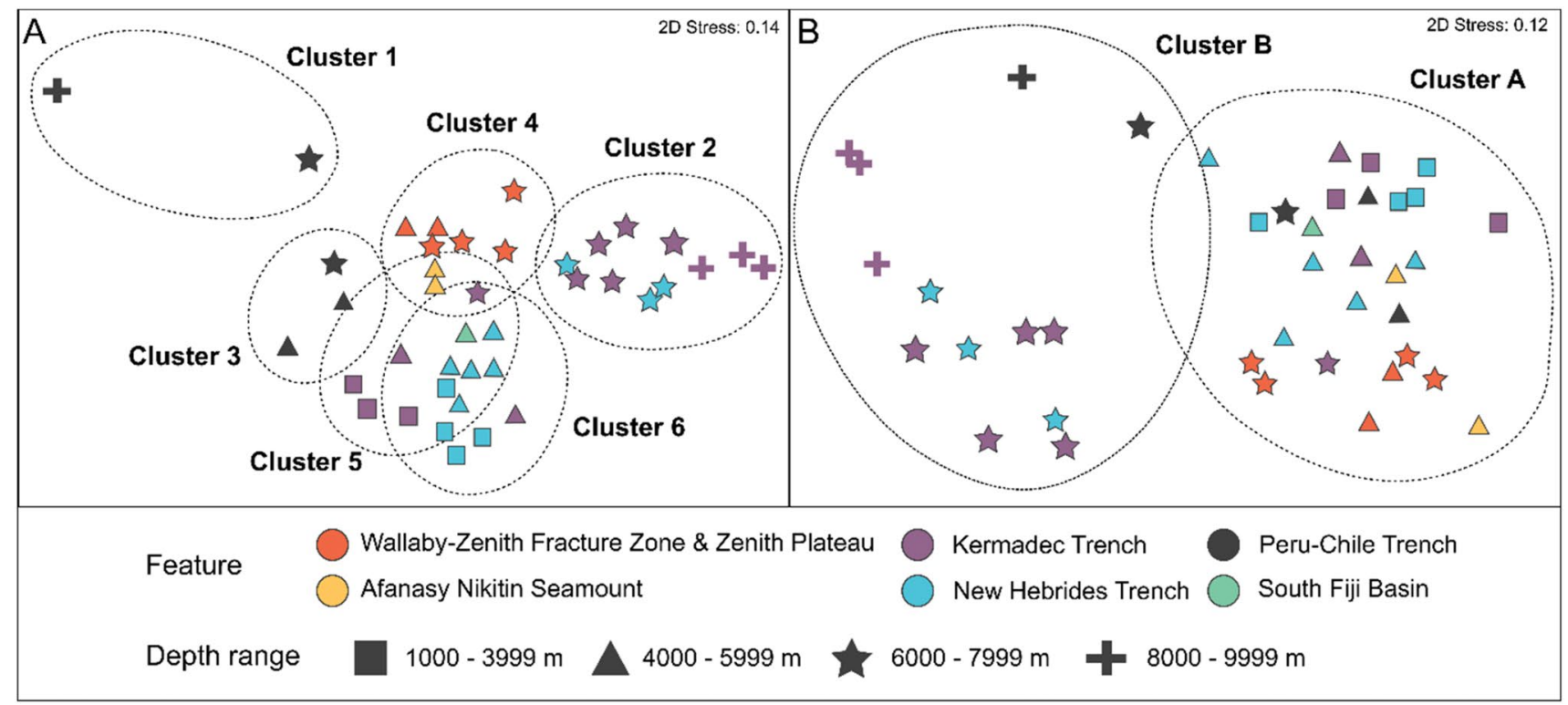

Fig. 3 Community structure and amphipod abundance in abyssal and hadal environments using non-metric multidimensional scaling ordination (nMDS): a Species-level identifications, and b Genus-level

equivalent to those identified by Lacey et al. (2016), with a slight exception to Clusters 3, 5, and 6 due to more accurate identification of Eurythenes spp. from the Peru Chile Trench (Eustace et al. 2016). Cluster 1 comprised two deep hadal sites from Peru Chile Trench. Cluster 2 contained the three hadal sites from New Hebrides Trench, and the eight sites deeper than $6097 \mathrm{~m}$ from Kermadec Trench. Cluster 3 comprised two abyssal sites and one shallow hadal site $(6173 \mathrm{~m})$ from Peru Chile Trench. Cluster 5 included the four bathyal sites, one abyssal site (4192 m), and one shallow hadal (6097 m) from Kermadec Trench. Cluster 6 comprised the four bathyal and five abyssal stations from New Hebrides Trench, all stations from South Fiji Basin (4100 m), and one abyssal site $(5242 \mathrm{~m})$ from Kermadec Trench. The average dissimilarity between Cluster 4 and the comparative clusters was $81.51 \%$, where the lowest dissimilarity was to Cluster 6 (New Hebrides Trench bathyal and abyssal; 71.88\%) and highest dissimilarity was to Cluster 1 (Peru-Chile Trench hadal; 97.52\%) (Table S4). The dissimilarity was attributed to at least five different species, where $P$. tenuipes consistently contributed the greatest to the difference in community assemblage (Table S4).

Two distinct communities were resolved when identification was to the genus-level (Fig. 3b). Cluster A comprised all the East Indian Ocean sites, the bathyal and abyssal comparison sites, and two hadal sites from the Kermadec and New Hebrides trenches. Cluster B contained 13 of the 14 hadal subduction trench sites. Similarity within Cluster A $(60.01 \%)$ was attributed to Paralicella and Abyssorchomene (Table S5). Whilst Cluster B had a lower similarity identifications. Colour denotes location, and shapes denote depth range of sampling sites. Encircling lines denote community grouping identified by SIMPROF

(55.63\%) and was defined by Hirondellea and Bathycallisoma. Between the two clusters, the dissimilarity level was $80.42 \%$ (Table S5). The near-exclusive presence of Hirondellea in Cluster B and Paralicella and Abyssorchomene in Cluster A accounted for $18.92 \%, 17.92 \%$, and $15.69 \%$ of the dissimilarity, respectively (Table S5). Bathycallisoma (14.97\%) and Eurythenes (10.96\%) also contributed to the dissimilarity between clusters, as presence and abundance varied at some depths (Table S5).

\section{Bathycallisoma schellenbergi demographics and phylogeography}

A total of 146 females, 138 males, 367 juveniles, and a single intersex individual were identified (Table S6). None of the females were ovigerous. Females were proportionally more abundant at $6537 \mathrm{~m}$ at $33.3 \%$ versus $19.7 \%$ at $6546 \mathrm{~m}$. A higher percentage of males were at the slightly deeper depth $(22.4 \%$ at $6546 \mathrm{~m}$ as compared to $16.3 \%$ at $6537 \mathrm{~m})$. Juveniles consisted of $49.6 \%$ of the population at $6537 \mathrm{~m}$ and $57.9 \%$ at $6546 \mathrm{~m}$. The male: female ratio was biased towards females at $6537 \mathrm{~m}(p<0.01)$. At $6456 \mathrm{~m}$, there were significantly more juveniles than mature amphipods $(p<0.001)$. At each depth, there was one juvenile cohort peak, two male cohort peaks, and three female cohort peaks (Fig. S4).

Species-delimitation analysis based on a concatenated topology resolved one species of $B$. schellenbergi across the five populations (acceptance rate: 0.1683 , merge: 49,976, split: 50,024, mean number of species: 3.67; Fig. 4). 
Fig. 4 Bayesian tree showing the relationship of $B$. schellenbergi from the Wallaby-Zenith Fracture Zone (bold blue) with four other populations using a combined dataset of $16 \mathrm{~S}$ rDNA and COI sequences (Table S3). Bayesian posterior probabilities and maximum-likelihood bootstrap supports are shown on branch nodes. Values less than 0.50 or values not supported by the alternative method are not stated or depicted by an asterisk. For the locations, $\mathrm{J}$ is Japan Trench, $\mathrm{K}$ is Kermadec Trench, M is Massau Trench, NH is New Hebrides Trench, T is Tonga Trench, and WZFZ is Wallaby-Zenith Fracture Zone. The depth (m) of the specimen is included if known

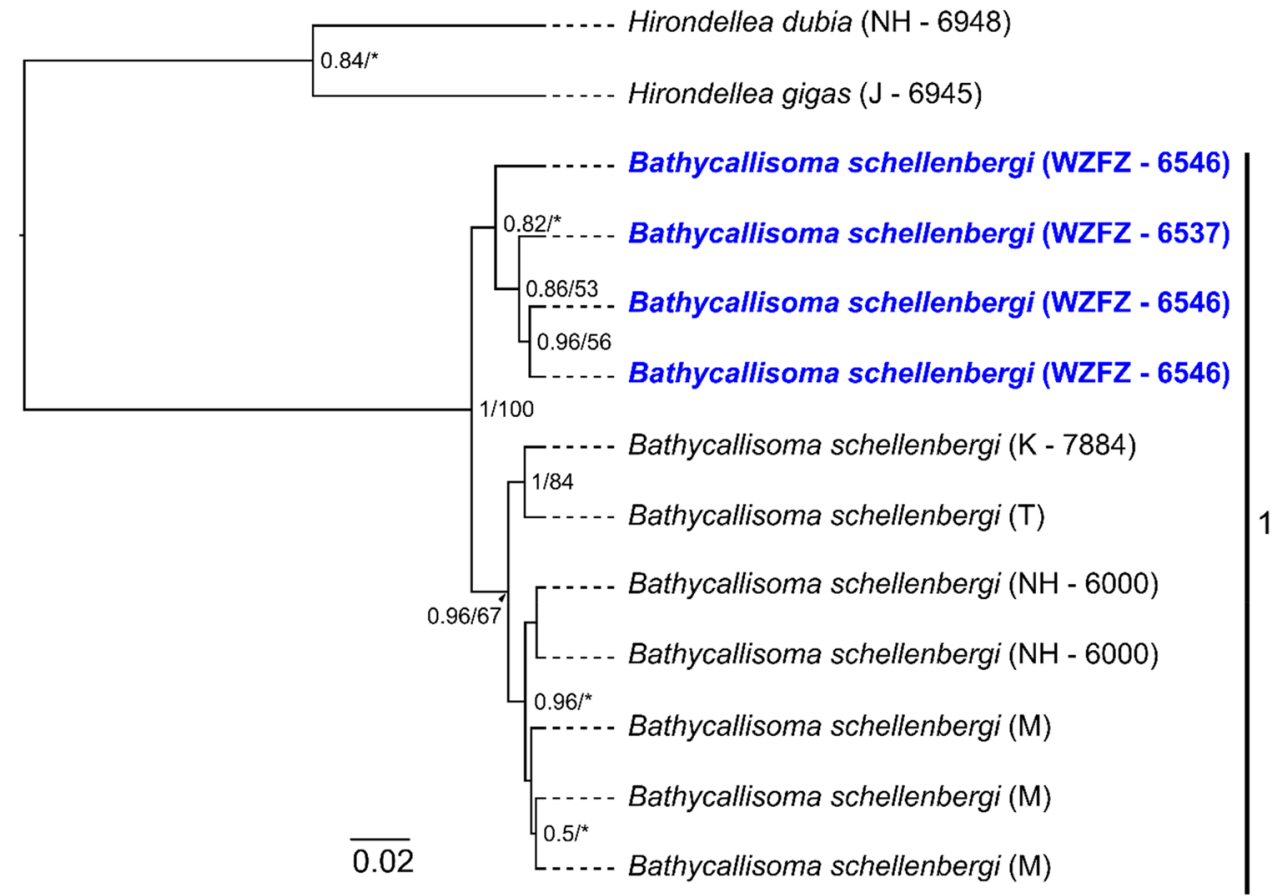

Geographic structuring of samples was apparent, with the WZFZ population and the four Pacific Ocean trench populations forming reciprocally monophyletic clades (posterior probability 0.85 ). Within the Pacific Ocean trench clade, two sub-groups were present: (1) the New Hebrides and Massau trenches (posterior probability 0.96), and (2) the Tonga and Kermadec trenches (posterior probability 1).

\section{Discussion}

The WZFZ was the first non-subduction hadal feature to be studied allowing us to further elucidate the effect of total area, topography, and total depth on scavenging amphipod community structure. This initial description of a hadal fracture zone highlights that whilst non-subduction features only account for a minor fraction of the global hadal area, sampling them is important to gain a more comprehensive understanding of drivers of community ecology and distribution of species at hadal depths.

\section{Non-subduction hadal habitat}

Whilst the geological and environmental survey of WZFZ showed similarities in temperature and seabed substrate to subduction trenches, there were also distinct habitat differences with respect total area and depth, and topography. The Zenith Plateau and WZFZ's temperature ranges and the seabed substrate, comprised fine-grained sediment and cobble-sized material, were comparable to subduction trenches (Lacey et al. 2016; Stewart and Jamieson 2018). However, the geomorphology of the WZFZ differed from subduction trenches concerning the total area, topography, and total depth (Jamieson et al. 2009a). When compared with hadal trenches, the WZFZ is small, with only $2.3 \%$ and $43.4 \%$ of the total area of the Kermadec Trench and New Hebrides Trench, respectively (Stewart and Jamieson 2018). Multibeam bathymetry mapping confirmed that the WZFZ was a flat-bottomed feature, lacking the characteristic V-shape cross-section of a subduction trench (Fig. S1). Mapping further showed the WZFZ to be $1158 \mathrm{~m}$ shallower than reported elsewhere (e.g., Smith and Marks 2014), albeit still hadal. The variation between satellite altimetry and multibeam measurements is not unique to the WZFZ, instead it is another instance highlighting the lack of fine-resolution topography data for the deep sea (Weatherall et al. 2015; Mayer et al. 2018; Stewart and Jamieson 2019).

\section{Scavenging amphipod community}

This study at the WZFZ and Afanasy Nikitin Seamount adds to the limited sampling of abyssal and hadal depth amphipods in the Indian Ocean (Birstein and Vinogradov 1964; Treude et al. 2002; Cousins et al. 2013), expands the known occurrence of some species and uncovers ultra-deep sea diversity. The two locations showed strong comparability in community assemblages possibility reflecting the same abyssal biogeographical province and comparability in abiotic conditions (Watling et al. 2013). The amphipods were from the Alicelloidea and 
Lysianassoidea superfamilies, which are both well-represented scavengers at these depths (Lacey et al. 2016). The only non-scavenger species identified was a single Cleonardo sp. indent. (Eusiroidea: Eusiridae) specimen from $6162 \mathrm{~m}$ in the WZFZ. This adds to the limited distribution data for this genus, with Cleonardo biscayensis Chevreux, 1908, Cleonardo maxima Birstein \& M. Vinogradov, 1964, and Cleonardo longipes Birstein \& M. Vinogradov, 1964 documented at abyssal depths in the northern Indian Ocean (Birstein and Vinogradov 1964; Hendrycks and Conlan 2003). From these two superfamilies, cosmopolitan species in the genera Paralicella, Abyssochromene, Eurythenes, and Cyclocaris were abundantly present (Duffy et al. 2016; Lacey et al. 2016). This study expanded the distribution of A. distinctus, A. gerliocoribis, $P$. tenupies, and $P$. caperesa from the Pacific and Atlantic Oceans and into the East Indian Ocean (Duffy et al. 2016; Lacey et al. 2016). Two species were found with their first known occurrence in the Indian Ocean: E. maldoror from the Weddell Sea, Argentinian Basin, and North Pacific Ocean (d'Udekem d'Acoz and Havermans 2015) and A. gigantea from the Pacific Ocean (Jamieson et al. 2013). The presence of E. maldoror and A. gigantea support the hypothesis that dispersal of these large amphipods across wide geographic distances could partially be attributed to deep-water circulation patterns, like the Antarctic Bottom Water, and their strong swimming ability (Havermans 2016). Bathycallisoma schellenbergi was abundantly present at the two deepest WZFZ sampling sites. In addition to common and cosmopolitan species, rare and possibly endemic species, such as $S$. sigmacrus and $C$. serendipia from $4932 \mathrm{~m}$ at the WZFZ (Weston et al. 2020) and the two specimens of Hirondellea sp. nov. from $4733 \mathrm{~m}$ at the Afanasy Nikitin Seamount, were also present. Valettietta sp. nov. was found in low numbers at both abyssal and hadal depths in the WZFZ. Whilst outside the scope of this study, Valettietta sp. nov. is likely to be a vicarious species with Valettietta gracilis Lincoln \& Thurston, 1983 and Valettietta anacantha (Birstein \& Vinogradov, 1963), which are considered to have disjunct distributions in the Atlantic and Pacific Oceans, respectively (Lincoln and Thurston 1983).

When compared to the South Fiji Basin and the Peru-Chile, Kermadec, and New Hebrides trenches, the amphipod community of the WZFZ and Afanasy Nikitin Seamount was found to be distinct at species-level identification (Cluster 4, Fig. 3a) and part of a bathyal and abyssal community assemblage with genus-level identifications (Group B, Fig. 3b). This highlights that community composition analysis can vary based on level identification as different genera have species with either broad or restricted geographic and or bathymetric distributions. Furthermore, the cluster analysis indicated the amphipod community at hadal depths of the WZFZ was an extension of the abyssal community, even with a large population of $B$. schellenbergi. This seemingly abyssal community was driven by the consistent abundance of $P$. tenuipes and the presence of Cyclocaris sp. nov. and P. caperesca, which are considered abyssal species with the physiological capability to live at shallow hadal depths (Lacey et al. 2016).

We interpret these results to indicate that the WZFZ exhibited a transitional amphipod community composition, with the abyssal community extending to hadal depths and with select hadal species, B. schellenbergi, present below $6500 \mathrm{~m}$. This gradual shift across the abyssal-hadal transition zone contrasts the ecotone community shifts observed in the Peru-Chile, Kermadec, and New Hebrides trenches between 6000 and $7000 \mathrm{~m}$ (Jamieson et al. 2011; Lacey et al. 2016). Jamieson et al. (2011) hypothesised that this biological shift between the two zones is not strictly driven by hydrostatic pressure but primarily by the change in seafloor topography from flat abyssal plains to the steep-sloped trench. The differences in topography and seismic activity between the abyssal plain and trenches result in distinct depositional environments and habitats (Ichino et al. 2015). Here in the WZFZ, the gradual change in the community assemblage across the abyssal-hadal transition zone is likely attributed to the similarities in the topography and depositional environments between the Zenith Plateau and the shallow, hadal basin. Further exploration is required to assess whether other similar hadal geomorphic features are also characterised by abyssal fauna with select hadal species.

Whilst the rate of community change across the abyssal-hadal transition zone contrasts between the WZFZ and hadal trenches, competitive exclusion appears to also occur in non-subduction systems. Bathycallisoma schellenbergi and $E$. maldoror show evidence for competitive exclusion, which prevents both large amphipod species with similar feeding ecologies to cohabitate at the WZFZ's maximum depths (Ingram and Hessler 1983; Blankenship and Levin 2007; Lacey et al. 2016). With E. maldoror being recovered across the entire sampling depth of WZFZ this suggests that E. maldoror is physiologically able to withstand the higher hydrostatic pressures (Downing et al. 2018). However, with the low number of E. maldoror individuals at the deepest depth $(6546 \mathrm{~m}), B$. schellenbergi potentially outcompetes it for food. Alternatively, the pressure adapted enzymes of $B$. schellenbergi (Downing et al. 2018) may be more efficient at increased pressure and/or E. maldoror may tolerate hadal pressure but pay a greater physiological cost.

\section{Bathycallisoma schellenbergi demographics and phylogeography}

Bathycallisoma schellenbergi were found at the $6537 \mathrm{~m}$ and $6546 \mathrm{~m}$ stations and comprised multiple stages of juveniles 
and adults, except for ovigerous females as consistent with other studies (Perrone et al. 2002, Blankenship et al. 2006; Eustace et al. 2013, 2016; Lacey et al. 2018). Whilst there were some significant differences between the sex ratios between the two depths, such a small difference in depth $(9 \mathrm{~m})$ is unlikely to drive the observed differences. This precludes drawing comparisons to ontogenetic vertical stratification patterns displayed by populations inhabiting hadal subduction trenches (Lacey et al. 2018). Differences in makeup could be explained by a combination of small-scale and non-depth related factors, such as topography, slope, and sediment type.

The WZFZ B. schellenbergi population does pose as an initial contrast with the lack of depth distribution of subduction trench populations (Blankenship et al. 2006; Lacey et al. 2018). Curiously, the WZFZ population's bathymetric range appeared to be compressed to less than $200 \mathrm{~m}$ from the floor of the fracture zone. It is unclear why B. schellenbergi were not present along the slope from the Zenith Plateau, as they have been known to have a shallower bathymetric range ( $5600 \mathrm{~m}$, Lacey et al. 2016). A possible explanation is that the slope does not provide suitable habitat as individuals were not recovered at intermediate depths. Future studies should consider increasing the number of sampling points on a transect or decreasing the vertical distance between sites to resolve the restricted bathymetric distributions in shallow hadal habitats.

Whilst B. schellenbergi has been recovered from several trenches (Kilgallen and Lowry 2015; Lacey et al. 2018), finding it in the relatively remote and small WZFZ was unexpected, and questions whether it is the same species. Indeed, B. schellenbergi has a complex systematic history, with a recent synonymization of Bathycallisoma pacific and Scopelocheirus schellenbergi (Kilgallen and Lowry 2015). However, in this case, individuals did not show morphological differences from the Dahl (1959) description and Kilgallen and Lowry (2015) re-description. DNA sequencing and phylogenetic analysis indicated that the species within the WZFZ is indeed B. schellenbergi (Fig. 4).

Whilst the mtDNA phylogeny resolved a single species, a degree of phylogeographic structure was observed between the five $B$. schellenbergi populations. There is a clear discontinuity between the WZFZ and the Pacific Ocean populations. A level of genetic differentiation is expected for the same species residing in two ocean basins, irrespective of whether they are demographically isolated or interconnected by unsampled intermediate populations (Ritchie et al. 2017). The low level of divergence between these clades is perhaps more suggestive of some connectivity given the amount of geological separation and hence the time required to accumulate more genetic differences, if not speciate entirely (Hendry et al. 2009). Additionally, there was a suggestion of phylogeographic structuring by distance between the
Pacific Ocean trenches, but this is less pronounced than might be expected given the reduced levels of geographic separation to facilitate even occasional gene flow (Ritchie et al. 2017). Whilst these phylogeographic patterns are preliminary and based on a relatively low number of individuals and genes, this finding does merit further investigation. A future genomics study should be aimed at assessing the extent to which hadal features represent demographically and evolutionary independent units, by leveraging highthroughput sequencing methods, such RAD-seq or microsatellites (Ritchie et al. 2017; Taylor and Roterman 2017). Bathycallisoma schellenbergi, $H$. dubia, $H$. gigas could be model species for this study, as they are found in several disjunct hadal features (Ritchie et al. 2015).

As B. schellenbergi are known from the Java Trench (Kilgallen and Lowry 2015), an obvious question is how they are present in the WZFZ, $2100 \mathrm{~km}$ south of Java Trench. Given this dataset indicates intra-specific levels of divergence amongst five populations, there are two plausible hypotheses for the presence of a population in the WZFZ. Firstly, the WZFZ may represent a spillover population from the larger Java Trench. This is plausible given that B. schellenbergi are strong swimmers and can tolerate shallower depths ( $5600 \mathrm{~m}$; Lacey et al. 2016). There are $\sim 1.4$ million $\mathrm{km}^{2}$ of discrete features deeper than $5600 \mathrm{~m}$ between the Java Trench and Diamantina Fracture Zone that could provide a complex corridor network for gene flow in the East Indian Ocean (Fig. 1a). A second possibility is that B. schellenbergi ancestrally had an abyssal-centric cosmopolitan distribution, analogous to A. gigantea or Paralicella spp., but subsequently became restricted to hadal depths (Jamieson et al. 2013; Corrigan et al. 2014). This is now reflected by allopatric populations in subduction trenches and non-subduction features, including the WZFZ. Whilst determining the mechanism the present-day distribution of B. schellenbergi is outside the scope this study, $B$. schellenbergi does present as a model taxon for future work to understand how the geological age and historical position of features, deepwater current patterns, and species' life history shape hadal fauna distributions and connectivity between features.

\section{Significance for hadal ecology}

Finding B. schellenbergi at hadal depths in the WZFZ indicates that characteristically hadal fauna, or fauna that are exclusively hadal elsewhere, has the potential to be found in non-subduction features. We now would expect to find $B$. schellenbergi populations at the Diamantina Fracture Zone and within the $5748 \mathrm{~km}^{2}$ of seafloor deeper than $6500 \mathrm{~m}$ in the Wharton Basin (Fig. 1a). Moreover, this finding in the East Indian Ocean could suggest there are other large swathes of seafloor hosting 
quintessentially hadal fauna, such as the North West Pacific Basin $(\sim 6500 \mathrm{~m})$, which is located between the Northern Mariana and Izu-Bonin trenches. Likewise, the Philippine Basin, between the Ryukyu and Philippine trenches, reaches hadal depths and may help explain why H. gigas is present in each of these trenches (France 1993). Non-subduction features could also explain the present distribution of other hadal fauna, such as the holothurian Prototrochus bruuni (Hansen, 1956) and the sea star Eremicaster vicinus Ludwig, 1907, found in many Pacific Ocean trenches (Jamieson 2015).

By concentrating sampling efforts on subduction trenches, the definition of hadal has been unintentionally restricted. The WZFZ indicates that from a biological perspective the hadal zone is more than the 27 subduction trenches and does encompass any location exceeding $6000 \mathrm{~m}$ regardless of geomorphic setting or total area. The community and population dynamics in these habitats are shaped not only by topography and total depth but also by resource limitations and physiological constraints. Thus, to unravel the ecological patterns of the ocean's deepest zone, sampling efforts and research programmes need to extend past the deepest point of large and often geographically isolated subduction trenches. Future efforts should focus on, or include, adjoining features such as fracture zones, troughs, and basins, as well as more detailed genetics studies to further disentangle the complexities of connectivity and species distribution in the hadal zone.

Acknowledgements We would like to thank Nick Cuomo for assistance with lander deployments, Prof Darren Evans and Dr James Kitson (Newcastle University, UK) for bench space in the Molecular Diagnosis Facility, Ed Hendrycks (Canadian Museum of Nature, Canada) for guidance on the Cleonardo sp. identification, and Dr Shannon Flynn (Newcastle University, UK) for constructive comments on manuscript drafts. We extend thanks to the Captain and crew on the $2017 \mathrm{R} / \mathrm{V}$ SONNE Expedition SO258 Leg 1, especially joint Chief Scientists Dr Reinhard Werner (GEOMAR, Germany) and Prof Hans-Joachim Wagner (University of Tübingen, Germany) and Oleg Lechenko and Julia Marinova (P.P. Shirshov Institute of Oceanology of the Russian Academy of Sciences, Russia) for the acquisition and processing of the bathymetric data. We are appreciative of the reviewers for their constructive comments and suggestions that improved the manuscript.

Author contributions This study was designed by AJJ and JNJW. The imaging and baited landers were designed, built, and deployed by AJJ and TDL. The amphipod samples were recovered by AJJ and TDL, and then processed and morphologically identified by JNJW and RAP. DNA barcoding was undertaken by JNJW, HR, and SBP. The data analysis was conducted by JNJW, HAS, and AJJ. All authors contributed to the writing and editing of the manuscript.

Funding Participation on the $R / V$ SONNE Expedition SO258 was supported by Newcastle University's Research Infrastructure Fund (RiF), Exploration of Extreme Ocean Environments, awarded to AJJ. The genetic analysis was funded by Newcastle University through internal funds to JNJW and the University of Aberdeen by the Natural
Environment Research Council (NERC), UK Grant NE/N01149X/1, awarded to SBP.

Data availability All genetic sequences have been deposited into NCBI GenBank under accession numbers MN251311-MN251335 for 16S sequences and MN26162-MN262182 for COI sequences.

\section{Compliance with ethical standards}

Conflict of interest The authors declare they have no competing or conflicts of interest.

Ethical approval All applicable international, national, and/or institutional guidelines for the care and use of animals were followed. All invertebrates sampled in this study were non-cephalopod.

Consent for publication HAS publishes with permission of the Executive Director of the British Geological Survey (UK Research and Innovation).

Open Access This article is licensed under a Creative Commons Attribution 4.0 International License, which permits use, sharing, adaptation, distribution and reproduction in any medium or format, as long as you give appropriate credit to the original author(s) and the source, provide a link to the Creative Commons licence, and indicate if changes were made. The images or other third party material in this article are included in the article's Creative Commons licence, unless indicated otherwise in a credit line to the material. If material is not included in the article's Creative Commons licence and your intended use is not permitted by statutory regulation or exceeds the permitted use, you will need to obtain permission directly from the copyright holder. To view a copy of this licence, visit http://creativecommons.org/licenses/by/4.0/.

\section{References}

Barnard JL, Ingram C (1990) Lysianassoid Amphipoda (Crustacea) from deep-sea thermal vents. Smithson Contrib Zool 499:1-80

Barnard JL, Karaman GS (1991) The families and genera of marine gammaridean Amphipoda (except marine gammaroids) Part 2. Rec Aust Mus suppl 13:419-866

Beliaev GM (1989) Deep sea ocean trenches and their fauna. Nauka Publishing House, Moscow

Birstein JA, Vinogradov ME (1964) Pelagic gammarid amphipods of the northern part of the Indian Ocean. Akademiya Nauk SSSR, Trudy Instituta Okeanologii 65:152-195

Blankenship LE, Levin LA (2007) Extreme food webs: foraging strategies and diets of scavenging amphipods from the ocean's deepest 5 kilometers. Limnol Oceanogr 52:1685-1697

Blankenship LE, Yayanos AA, Cadien DB, Levin LA (2006) Vertical zonation patterns of scavenging amphipods from the hadal zone of the Tonga and Kermadec Trenches. Deep-Sea Res I 53:48-61

Clarke KR, Gorley RN (2015) PRIMER v7: user manual/tutorial. Plymouth Marine Laboratory, Plymouth

Clarke KR, Somerfield PJ, Gorley RN (2008) Testing the null hypotheses in exploratory community analyses: similarity profiles and biota environmental linkage. J Exp Mar Biol Ecol 366:56-69. https://doi.org/10.1016/j.jembe.2008.07.009

Corrigan LJ, Horton T, Fotherby H, White TA, Hoelzel AR (2014) Adaptive evolution of deep-sea amphipods from the superfamily Lysiassanoidea in the North Atlantic. Evolut Biol 41:154-165. https://doi.org/10.1007/s11692-013-9255-2 
Cousins NJ, Horton T, Wigham BD, Bagley PM (2013) Abyssal scavenging demersal fauna at two areas of contrasting productivity on the Subantarctic Crozet Plateau, southern Indian Ocean. Afr J Mar Sci 35:299-306. https://doi.org/10.2989/1814232X.2013.802747

d'Udekem d'Acoz C, Havermans C (2015) Contribution to the systematics of the genus Eurythenes S.I Smith in Scudder 1882 (Crustacea: Amphipoda: Lysianassoidea: Eurytheneidae). Zootaxa 3971:1-80. https://doi.org/10.11646/zootaxa.4196.3.9

Dahl E (1959) Amphipoda from depths exceeding $6000 \mathrm{~m}$. Galathea Rep 1:211-240

Daniell J, Jorgensen DC, Anderson T, Borissova I, Burq S, Heap A, Hughes M, Mantle D, Nelson G, Nichol S, Nicholson C, Payne D, Przeslawski R, Radke L, Siqabessy J, Smith C, Shipboard Party (2010) Frontier basins of the West Australian Continental Margin: post-survey report of marine reconnaissance and geological sampling survey GA2476. Geoscience Australia, Canberra

Downing AB, Wallace GT, Yancey PH (2018) Organic osmolytes of amphipods from littoral to hadal zones: Increases with depth in trimethylamine $\mathrm{N}$-oxide, scyllo-inositol and other potential pressure counteractants. Deep-Sea Res I 138:1-10. https://doi. org/10.1016/j.dsr.2018.05.008

Drummond AJ, Suchard MA, Xie D, Rambaut A (2012) Bayesian phylogenetics with BEAUti and the BEAST 1.7. Mol Biol Evol 29:1969-1973. https://doi.org/10.1093/molbev/mss075

Duffy GA, Gutteridge ZRS, Thurston MH, Horton T (2016) A comparative analysis of canyon and non-canyon population of the deepsea scavenging amphipod Paralicella caperesca. J Mar Biol Assoc UK 96:1687-1699. https://doi.org/10.1017/S0025315415002064

Eustace RM, Kilgallen NM, Lacey NC, Jamieson AJ (2013) Population structure of the hadal amphipod Hirondellea gigas (Amphipoda: Lysianassoidea) from the Izu-Bonin Trench. J Crust Biol 33:793-801. https://doi.org/10.1163/1937240X-00002193

Eustace RM, Kilgallen NM, Ritchie H, Piertney SB, Jamieson AJ (2016) Morphological and ontogenetic stratification of abyssal and hadal Eurythenes gryllus (Amphipoda: Lysianassidae) from the Peru-Chile Trench. Deep-Sea Res I 109:91-98. https://doi. org/10.1016/j.dsr.2015.11.005

Folmer O, Black M, Hoeh W, Lutz R, Vrijenhoek R (1994) DNA primers for amplification of mitochondrial cytochrome $\mathrm{c}$ oxidase subunit I from diverse metazoan invertebrates. Mol Mar Biol Biotechnol 3:294-299

France SC (1993) Geographic variation amount three isolated populations of the hadal amphipod Hirondellea gigas (Crustacea: Amphipoda: Lysianassoidea). Mar Ecol Prog Ser 92:277-287

France SC, Kocher TD (1996) Geographic and bathymetric patterns of mitochondrial 16S rRNA sequence divergence amount deep-sea amphipods, Eurythenes gryllus. Mar Biol 126:633-643

Fujii T, Kilgallen NM, Rowden AA, Jamieson AJ (2013) Deep-sea amphipod community structure across abyssal to hadal depths in the Peru-Chile and Kermadec trenches. Mar Ecol Prog Ser 492:125-138. https://doi.org/10.3354/meps10489

Guindon S, Dufayard JF, Lefort V, Anisimova M, Hordijk W, Gascuel O (2010) New algorithms and methods to estimate maximumlikelihood phylogenies: assessing the performance of PhyML 3.0. Syst Biol 59:307-321. https://doi.org/10.1093/sysbio/syq010

Hasegawa M, Kishino H, Yano T (1985) Dating the human-ape splitting by a molecular clock of mitochondrial DNA. Mol Evol $22: 160-174$

Havermans C (2016) Have we so far only seen the tip of the iceberg? Exploring species diversity and distribution of the giant amphipod Eurythenes. Biodiversity 17:12-25. https://doi.org/10.1080/14888 386.2016.1172257

Hendry AP, Bolnick DI, Berner D, Peichel CL (2009) Along the speciation continuum in sticklebacks. J Fish Biol 75:2000-2036. https ://doi.org/10.1111/j.1095-8649.2009.02419.x
Hendrycks EA, Conlan KE (2003) New and unusual abyssal gammaridean Amphipoda from the north-east Pacific. J Nat Hist 37:23032368. https://doi.org/10.1080/00222930210138926

Hessler RR, Ingram CL, Yayanos AA, Burnett BR (1978) Scavening amphipods from the floor of the Philippine Trench. Deep-Sea Res 25:1029-1047

Hiraoka S, Hirai M, Matsui Y, Makabe A, Minegishi H, Tsuda M, Rastelli E, Danovaro R, Corinaldesi C, Kitahashi T, Tasumi E (2020) Microbial community and geochemical analyses of trans-trench sediments for understanding the roles of hadal environments. ISME J 143:740-756. https://doi.org/10.1038/s41396-019-0564-Z

Ichino MC, Clark MR, Drazen JC, Jamieson A, Jones DO, Martin AP, Rowden AA, Shank TM, Yancey PH, Ruhl HA (2015) The distribution of benthic biomass in hadal trenches: a modelling approach to investigate the effect of vertical and lateral organic matter transport to the seafloor. Deep-Sea Res I 100:21-33. https ://doi.org/10.1016/j.dsr.2015.01.010

Ingram CL, Hessler RR (1983) Distribution and behavior of scavenging amphipods from the central North Pacific. Deep-Sea Res I 30:683-706

Jamieson AJ (2015) The hadal zone: life in the deepest oceans. Cambridge University Press, Cambridge

Jamieson AJ (2018) A contemporary perspective on hadal science. Deep-Sea Res II 155:4-10. https://doi.org/10.1016/j. dsr2.2018.01.005

Jamieson AJ, Kilgallen NM, Rowden AA, Fujii T, Horton T, Lorz AN, Kitazawa K, Priede IG (2011) Bait-attending fauna of the Kermadec Trench, SW Pacific Ocean: Evidence for an ecotone across the abyssal-hadal transition zone. Deep-Sea Res I 58:49-62. https:// doi.org/10.1016/j.dsr.2010.11.003

Jamieson AJ, Lacey NC, Lörz AN, Rowden AA, Piertney SB (2013) The supergiant amphipod Alicella gigantea (Crustacea: Alicellidae) from hadal depths in the Kermadec Trench, SW Pacific Ocean. Deep-Sea Res II 92:107-113. https://doi.org/10.1016/j. dsr2.2012.12.002

Jamieson AJ, Fujii T, Mayor DM, Solan M, Priede IG (2009a) Hadal trenches: the ecology of the deepest places on Earth. Trends Ecol Evol 25:190-197. https://doi.org/10.1016/j.tree.2009.09.009

Jamieson AJ, Fujii T, Solan M, Priede IG (2009b) HADEEP: freefalling landers to the deepest places on Earth. Mar Technol Soc J 43:151-160. https://doi.org/10.4031/MTSJ.43.5.17

Jażdżewska AM, Mamos T (2019) High species richness of Northwest Pacific deep-sea amphipods revealed through DNA barcoding. Prog Oceanogr 178:102184. https://doi.org/10.1016/j.pocea n.2019.102184

Katoh K, Rozewicki J, Yamada KD (2017) MAFFTA online service: multiple sequence alignment, interactive sequence choice and visualization. Brief Bioinform. https://doi.org/10.1093/bib/bbx108

Kilgallen NM (2015) Three new species of Hirondellea (Crustacea, Amphipoda, Hirondelleidae) from hadal depths of the Peru-Chile Trench. Mar Biol Res 11:34-48. https://doi.org/10.1080/17451 000.2014 .889309

Kilgallen NM, Lowry JK (2015) A review of the scopelocheirid amphipods (Crustacea, Amphipoda, Lysianassoidae), with the description new taxa from Australian waters. Zoostem Evol 91:1-43. https://doi.org/10.3897/zse.91.8440

Krishna KS, Bull JM, Ishizuka O, Scrutton RA, Jaishankar S, Banakar VK (2014) Growth of the Afanasy Nikitin seamount and its relationship with the $85^{\circ} \mathrm{E}$ Ridge, northeastern Indian Ocean. J Earth Syst Sci 123:33-47

Kumar S, Stecher G, Tamura K (2016) MEGA7: molecular evolutionary genetics analysis version 7.0 for bigger datasets. Mol Biol Evol 33:1870-1874. https://doi.org/10.1093/molbev/msw054

Lacey NC, Rowden AA, Clark MR, Kilgallen NM, Linley T, Mayor DJ, Jamieson AJ (2016) Community structure and diversity of scavenging amphipods from bathyal to hadal depths in three 
South Pacific Trenches. Deep-Sea Res I 111:121-137. https:// doi.org/10.1016/j.dsr.2016.02.014

Lacey NC, Mayor DJ, Linley TD, Jamieson AJ (2018) Population structure of the hadal amphipod Bathycallisoma (Scopelocheirus) schellenbergi in the Kermadec Trench and New Hebrides Trench, SW Pacific. Deep Sea Res II 155:50-60. https://doi.org/10.1016/j. dsr2.2017.05.001

Lincoln RJ, Thurston MH (1983) Valettietta, a new genus of deep-sea amphipod (Gammaridae: Lysianassidae) with descriptions of two new species from the North Atlantic Ocean. Bull Br Mus Nat I 44:85-101

Linley TD, Gerringer ME, Yancey PH, Drazen JC, Weinstock CL, Jamieson AJ (2016) Fishes of the hadal zone including new species, in situ observations and depth records of Liparidae. DeepSea Res I 114:99-110. https://doi.org/10.1016/j.dsr.2016.05.003

Linley TD, Stewart AL, McMillan PJ, Clark MR, Gerringer ME, Drazen JC, Fujii T, Jamieson AJ (2017) Bait attending fishes of the abyssal zone and hadal boundary: community structure, functional groups and species distribution in the Kermadec, New Hebrides and Mariana trenches. Deep-Sea Res I 121:38-53. https://doi. org/10.1016/j.dsr.2016.12.009

Longhurst A, Sathyendranath S, Platt T, Caverhill C (1995) An estimate of global primary production in the ocean from satellite radiometer data. J Plankton Res 17:1245-1271

Lowry JK, De Broyer C (2008) Alicellidae and Valettiopsidae, two new callynophorate families (Crustacea: Amphipoda). Zootaxa 1843:57-66

Lowry JK, Kilgallen NM (2014) A generic review of the lysianassoid family Uristidae and descriptions of new taxa from Australian waters (Crustacea, Amphipoda, Uristidae). Zootaxa 3867:1-92. https://doi.org/10.11646/zootaxa.3867.1.1

Macdonald PDM (2018) mixdist: finite mixture distribution models. $\mathrm{R}$ package version 0.5-4. https://cran.r-project.org/web/packages/ mixdist/index.html. Accessed 17 Mar 2018

Marghany M, Mansor S, Shariff ARBM (2016) Genetic algorithm for investigating flight MH370 in Indian Ocean using remotely sensed data. IOP Conf Ser Earth Environ Sci 37:012001. https:// doi.org/10.1088/1755-1315/37/1/012001

Mayer L, Jakobsson M, Allen G, Dorschel B, Falconer R, Ferrini V, Lamarche G, Snaith H, Weatherall P (2018) The nippon foundation-GEBCO seabed 2030 project: the quest to see the world's oceans completely mapped by 2030 . Geosciences 8:63. https:// doi.org/10.3390/geosciences8020063

Olierrok HKH, Merle RE, Jourdan F, Sircombe K, Fraser G, Timms NE, Nelson F, Dadd KA, Kellerson L, Borissova I (2015) Age and geochemistry of magmatism on the oceanic Wallaby Plateau and implications for the opening of the Indian Ocean. Geology 43:971-974. https://doi.org/10.1130/G37044.1

Palumbi S, Martin A, Romano S (2002) The simple fool's guide to PCR, version 2.0. Department Zoology, University of Hawaii

Perrone FM, Dell'Anno A, Danovaro R, Della Croce N, Thurston MH (2002) Population biology of Hirondellea sp. nov. (Amphipoda: Gammaridea: Lysianassoidea) from the Atacama Trench (southeast Pacific Ocean). J Mar Biol Assoc UK 82:419-425. https:// doi.org/10.1017/S0025315402005672

R Core Team (2017). R: a language and environment for statistical computing. R Foundation for Statistical Computing, Vienna, Austria. https://www.R-project.org. Accessed 15 Nov 2017

Rambaut A, Drummond AJ, Xie D, Baele G, Suchard MA (2018) Tracer v1.7. https://tree.bio.ed.ac.uk/software/tracer. Accessed 10 Mar 2018

Ritchie H, Jamieson AJ, Piertney SB (2015) Phylogenetic relationships among hadal amphipods of the superfamily Lysianassoidea: implications for taxonomy and biogeography. Deep-Sea Res I 105:119-131. https://doi.org/10.1016/j.dsr.2015.08.014
Ritchie H, Jamieson AJ, Piertney SB (2017) Population genetic structure of two congeneric deep-sea amphipod species from geographically isolated hadal trenches in the Pacific Ocean. Deep-Sea Res I 119:50-57. https://doi.org/10.1016/j.dsr.2016.11.006

Ryan WBF, Carbotte SM, Coplan JO, O'Hara S, Melkonian A, Arko R, Weissel RA, Ferrini V, Goodwillie A, Nitsche F, Bonczkowski J, Zemsky R (2009) Global Multi-resolution topography synthesis. Geochem Geophys Geosyst 10:Q03014. https://doi. org/10.1029/2008GC002332

Saunders PM (1981) Practical conversion of pressure to depth. J Phy Oceanogr 11:573-574

Sborshchikov IM, Murdmaa IO, Matveenkov VV, Kashintsev GL, Golmshtock AI, Al'Mukhamedov AI (1995) Afanasy Nikitin Seamount within the intraplate deformation zone, Indian Ocean. Mar Geo 128:115-126. https://doi.org/10.1016/0025-3227(95)01995 $-\mathrm{G}$

Schliep KP (2011) Phangorn: phylogenetic analysis in R. Bioinformatics 27:592-593. https://doi.org/10.1093/bioinformatics/btq706

Schliep K, Potts AJ, Morrison DA, Grimm GW (2017) Intertwining phylogenetic trees and networks. Methods Ecol Evol 8:1212-1220

Sclater JG, Fisher RL (1974) Evolution of the east: Central Indian Ocean, with emphasis on the tectonic setting of the Ninetyeast Ridge. Geo Soc Am Bull 85:683-702. https://doi. org/10.1130/0016-7606(1974)85<683:EOTECI >2.0.CO;2

Smith WHF, Marks KM (2014) Seafloor in the Malaysian Airlines flight MH370 search area. Eos 95:173-180

Stewart HA, Jamieson AJ (2018) Habitat heterogeneity of hadal trenches: consideration and implications for future studies. Prog Oceanogr 161:47-65. https://doi.org/10.1016/j.pocea n.2018.01.007

Stewart HA, Jamieson AJ (2019) The five deeps: the location and depth of the deepest place in each of the world's oceans. Earth Sci Rev 197:102896. https://doi.org/10.1016/j.earscirev.2019.102896

Taylor ML, Roterman CN (2017) Invertebrate population genetics across earth's largest habitat: the Deep-sea floor. Mol Ecol 26:4872-4896. https://doi.org/10.1111/mec.14237

Treude T, Janßen F, Queisser W, Witte U (2002) Metabolism and decompression tolerance of scavenging lysianassoid deepsea amphipods. Deep-Sea Res I 49:1281-1289. https://doi. org/10.1016/S0967-0637(02)00023-7

Veevers JJ, Cotterill D (1978) Western margin of Australia: evolution of a rifted arch system. Geol Soc Am Bull 89:337-355

Watling L, Guinotte J, Clark MR, Smith CR (2013) A proposed biogeography of the deep ocean floor. Prog Oceanogr 111:91-112. https://doi.org/10.1016/j.pocean.2012.11.003

Weatherall P, Marks KM, Jakobsson M, Schmitt T, Tani S, Arndt JE, Rovere M, Chayes D, Ferrini V, Wigley R (2015) A new digital bathymetric model of the world's oceans. Earth Space Sci 2:331345. https://doi.org/10.1002/2015EA000107

Werner R, Wagner HJ, Hauff F (2017) RV SONNE Fahrtbericht/ Cruise report SO258/1: INGON: The Indian - Antarctic Breakup Engima, Fremantle (Australia) - Colombo (Sri Lanka) 07.06.-09.07.2017. GEOMAR Report, N. Ser. 038. GEOMAR Helmholtz-Zentrum für Ozeanforschung Kiel, Kiel. https://doi. org/10.3289/GEOMAR_REP_NS_38_2017. Accessed 1 Aug 2020

Weston JNJ, Peart RA, Jamieson AJ (2020) Amphipods from the Wallaby-Zenith Fracture Zone, Indian Ocean: new genus and two new species identified by integrative taxonomy. Syst Biol 18:57-78. https://doi.org/10.1080/14772000.2020.1729891

White LT, Gibson GM, Lister GS (2013) A reassessment of paleogeographic reconstructions of eastern Gondwana: Bringing geology back into the equation. Gondawana Res 24:984-998. https://doi. org/10.1016/j.gr.2013.06.009

Wolff T (1960) The hadal community, an introduction. Deep-Sea Res 6:95-124 
Wolff T (1970) The concept of the hadal or ultra-abyssal fauna. DeepSea Res 17:983-1003

Zhang J, Kapli P, Pavlidis P, Stamatakis A (2013) A general species delimitation method with applications to phylogenetic placements. Bioinformatics 29:2869-2876. https://doi.org/10.1093/bioinforma tics/btt499
Publisher's Note Springer Nature remains neutral with regard to jurisdictional claims in published maps and institutional affiliations. 